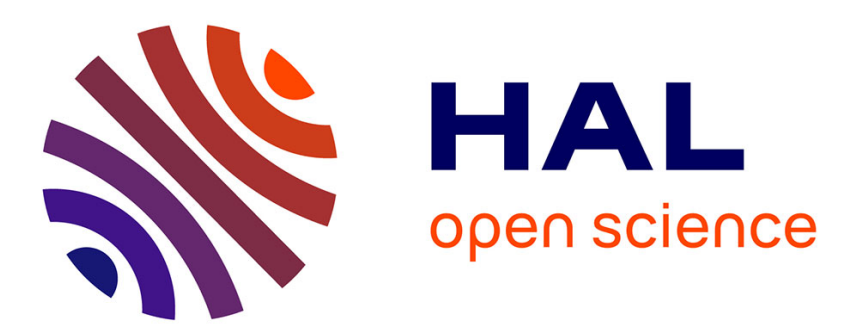

\title{
Ocean Wave Converters: State of the Art and Current Status
}

Mouna Lagoun, Atallah Benalia, Mohamed Benbouzid

\section{To cite this version:}

Mouna Lagoun, Atallah Benalia, Mohamed Benbouzid. Ocean Wave Converters: State of the Art and Current Status. 2010 IEEE International Energy Conference, Dec 2010, Manama, Bahrain. pp.636641. hal-00599003

\section{HAL Id: hal-00599003 https://hal.science/hal-00599003}

Submitted on 8 Jun 2011

HAL is a multi-disciplinary open access archive for the deposit and dissemination of scientific research documents, whether they are published or not. The documents may come from teaching and research institutions in France or abroad, or from public or private research centers.
L'archive ouverte pluridisciplinaire HAL, est destinée au dépôt et à la diffusion de documents scientifiques de niveau recherche, publiés ou non, émanant des établissements d'enseignement et de recherche français ou étrangers, des laboratoires publics ou privés. 


\title{
Ocean Wave Converters: State of the Art and Current Status
}

\author{
M.S. Lagoun ${ }^{1,2}$, A. Benalia ${ }^{2}$ and M.E.H Benbouzid ${ }^{1}$ \\ ${ }^{1}$ University of Brest, EA 4325 LBMS \\ Rue de Kergoat, CS 93837, 29238 Brest Cedex 03, France \\ University of Laghouat, LACoSERE, Laghouat, Algeria \\ lagoun_mona@yahoo.fr, atabenalia@yahoo.fr and Mohamed.Benbouzid@univ-brest.fr
}

\begin{abstract}
Solutions to today energy challenges need to be explored through alternative, renewable and clean energy sources to enable a diverse energy resource plan. An extremely abundant and promising source of energy exists in oceans. Ocean energy exists in many forms. Among these forms, significant opportunities and benefits have been identified in the area of ocean wave energy extraction, i.e., harnessing the wave motions and converting them into electrical energy.

Regarding this emerging and promising area of research, this paper presents ocean wave energy fundamentals and then reviews the fundamental concepts and the main projects around the world. It also reports issues regarding electrical generator topologies associated to wave energy converters.
\end{abstract}

Index Terms-Wave Energy Converter (WEC), electric power generation, generator, state of the art.

\section{INTRODUCTION}

The environment pollution and energy crisis are the two most concerned problems around the world. In order to solve these problems, renewable energy was developed to replace part of the energy supply. Among renewable energy harvesting technologies which are still being investigated through various industrial and academic group, wave energy harvesting technology has already shown to be practical, since oceans cover almost $70 \%$ of the earth's surface [1-2].

The energy is stored in oceans partly as thermal energy, partly as kinetic energy (waves and currents) and also in chemical and biological products. Numerous techniques for extracting energy from the sea have been suggested, most of which can be included in one of the following categories: wave energy, marine and tidal current energy, ocean thermal energy, energy from salinity gradients (osmosis), and cultivation of marine biomass [3].

Waves are a very promising energy carrier among renewable power sources, since they are able to manifest an enormous amount of energy resources in almost all geographical regions. The global theoretical energy from waves corresponds to $8 \times 106 \mathrm{TWh} /$ year, which is about 100 times the total hydroelectricity generation of the whole planet [3].

To harness the power energy in waves present a different set of technical challenges and a wide variety of designs have been suggested. This paper will therefore describe the wave energy resource and its calculation. Then a classification of wave energy converters is given. It is followed by a discussion of the main projects around the world. Finally, the main generator topologies used for electricity generation are briefly presented.

\section{WAVE ENERGY BACKGROUND}

\section{A. Wave Energy Resource}

Ocean Wave energy is a concentrated form of solar energy: the sun produces temperature differences across the globe, causing winds that blow over the ocean surface. These cause ripples, which grow into swells. Such waves can then travel thousands of miles with virtually no loss of energy [1].

Most importantly, waves are a regular source of power with an intensity that can be accurately predicted several days before their arrival [1]. Furthermore, wave energy is more predictable than wind or solar energy.

Figure 1 show an Atlas of the global power density distribution of the oceans where the numbers indicate $\mathrm{kW} / \mathrm{m}$. The north and south temperature zones have the best sites for capturing wave power. The prevailing winds in these zones blow strongest in winter. Increased wave activity is found between the latitudes of $30^{\circ}$ and $60^{\circ}$ on both hemispheres, induced by the prevailing western winds blowing in these regions.

\section{B. Wave Energy and Power}

The energy density of a wave is the mean energy flux crossing a vertical plane parallel to the wave crest. This energy and the power density are given by [4]

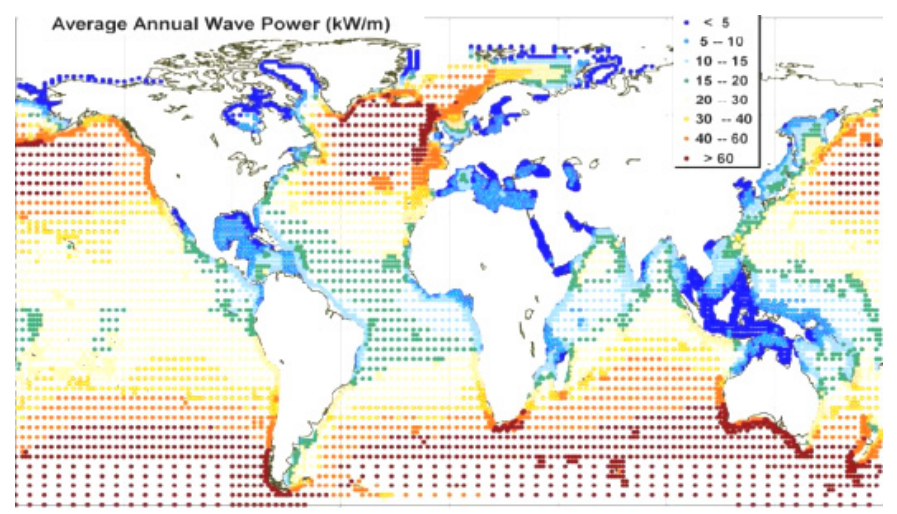

Fig. 1. Approximate global distribution of wave power levels $(\mathrm{kW} / \mathrm{m}$ of wave front) [C WorldWaves data]. 
$\left\{\begin{array}{l}E_{D}=\frac{1}{2} \rho g A^{2} \\ P_{D}=\frac{1}{2 T} \rho g A^{2}\end{array}\right.$

where $\rho$ is the water density (approximately $1000 \mathrm{~kg} / \mathrm{m}^{3}$ ), $g$ is the gravity acceleration, $A$ is the wave amplitude, and $T$ the wave period.

A wave resource is typically described in terms of power per meter of wave front (wave crest length) [5].

$$
P_{w_{-} f}=\frac{1}{8 \pi} \rho g^{2} A^{2} T
$$

It can also be described in terms of wave power per meter crest length $\left(P_{w \_m c l}\right)$ (Fig. 2).

$$
P_{w_{-} m c l}=\frac{1}{32 \pi} \rho g^{2} H^{2} T
$$

It should be noted that the wave height $H$ is historically defined as equal to $2 A$.

The salient features of (3) to note is that the wave power is proportional to the wave height squared, proportional to the square root of wavelength and linearly proportional to the wave period.

For illustration, Fig. 3 shows how wave period and amplitude affect the power.

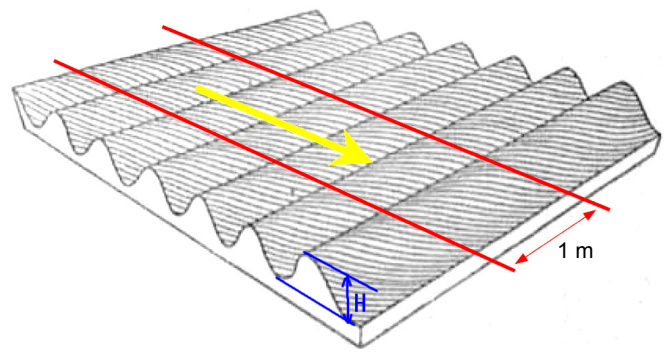

Fig. 2. Wave dimensions.

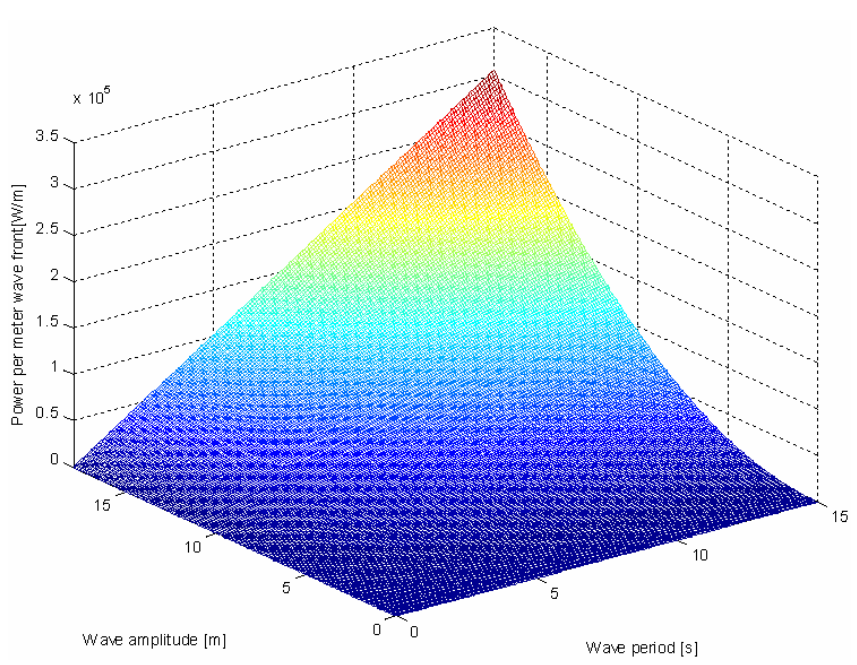

Fig. 3. Power per meter of wave front.

\section{WAVE ENERGY CONVERTERS}

Waves have the potential to provide a completely sustainable source of energy which can be captured and converted into electricity by wave energy converters. These WECs have been developed to extract energy from shoreline out to the deeper waters offshore. These devices are generally categorized by the installation location and the Power Take-Off (PTO) system.

Locations are shoreline, near shore and offshore. Therefore, most devices can be characterized as belonging to six types [6]. These are Attenuator; Point absorber; Oscillating wave surge converter; Oscillating water column; Overtopping device; Submerged pressure differential (Fig. 4).

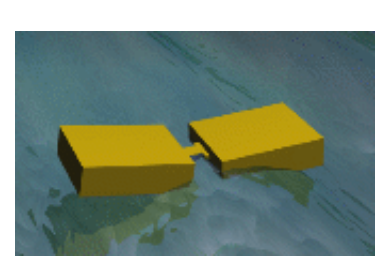

(a) Attenuator

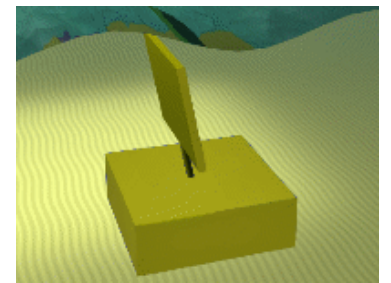

(c) Oscillating wave surge converter

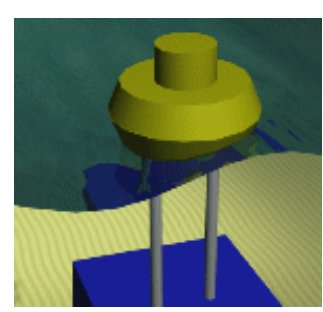

(b) Point absorber.

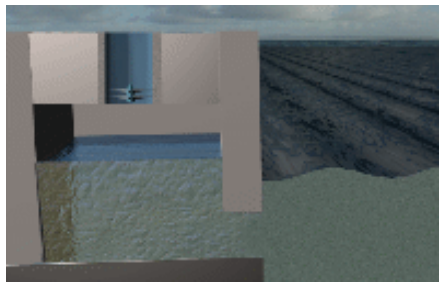

(d) Oscillating water column.

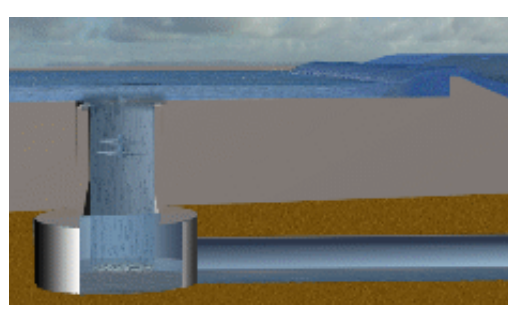

(e) Overtopping device

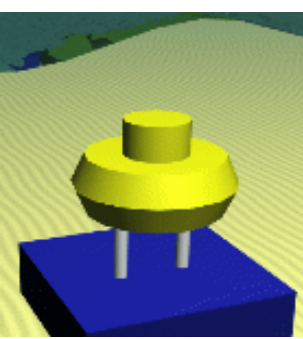

(f) Submerged pressure differential
Fig. 4. WEC types [C EMEC].

\section{A. Attenuator}

An attenuator is a floating device which works parallel to the wave direction and rides the waves (Fig. 4a). Movements along its length can be selectively constrained to produce energy. It has a lower area parallel to the waves. This is the case of the PELAMIS WEC.

PELAMIS project (Portugal) [7]: Pelamis is a wave power generator which has been successfully installed three miles off the northern coast of Portugal (Fig. 5). This is the first commercial scale wave power station in the world. The sea snake-like device is made up of a series of three semi-submerged cylinders linked by hinged joints. Each cylinder has a 3.5-m diameter and is made from 700-tones of carbon steel. The motion of each hinge is resisted by hydraulic rams driving generators which produce electricity. The power conversion units in each 140-m long Pelamis P-750s generates up to $750-\mathrm{kW}$. 


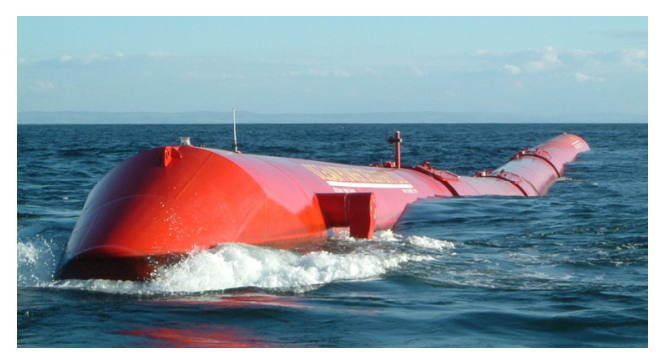

(a) Installation.

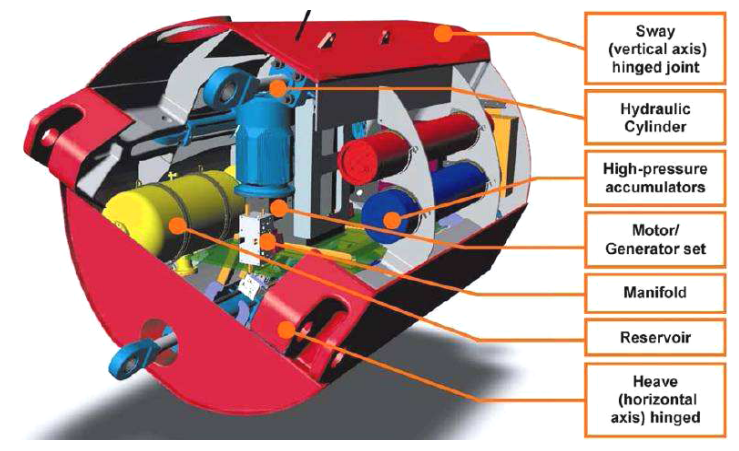

(b) Module.

Fig. 5. The PELAMIS wave energy converter [C Pelamis Wave Power].

\section{B. Point Absorber}

Point absorbers, often simply called a buoy, are relatively small devices in comparison to other WEC types (Fig. 4b). They are typically cylindrical in shape and constrained to one major motion degree, usually up-and-down. They are generally significantly smaller in diameter than a wavelength. A point absorber harvests energy in all directions through its movements at/near the water surface. The PTO system may take a number of forms as the following main projects.

1) CETO project (Australia) [8]. The CETO system distinguishes itself from other traditional WEC by being a fully submerged, pumping technology with the power generated onshore by a standard hydroelectric turbine system (Fig. 6). The high-pressure seawater is also used to supply a reverse osmosis desalination plant.

2) SEAREV project (France) [9]. The SEAREV WEC is a floating device enclosing a heavy horizontal axis wheel serving as an internal gravity reference (Fig. 7). The wheel gravity centre being off-centered, this component behaves mechanically like a pendulum. The rotational motion of this pendulum wheel relative to the hull activates a hydraulic PTO system which, in turn, set an electric generator into motion. Two major advantages of this arrangement are; (1) All the moving parts (mechanic, hydraulic, electric, components) are sheltered from the sea action inside a closed and waterproof shell. (2) A wheel pendulum involves neither end stop nor any security system limiting the stroke [10].

\section{Oscillating Wave Surge Converter}

This device extracts both the wave surges and its particle motion energies. The WEC arm oscillates as a pendulum mounted on a pivoted joint in response to the water motion due to waves (Fig. 4c). This is the case of the OYSTER WEC.

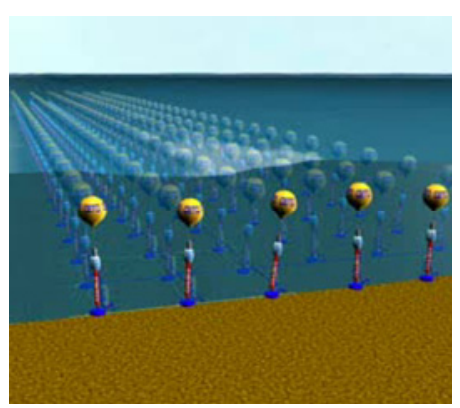

(a) Farm.

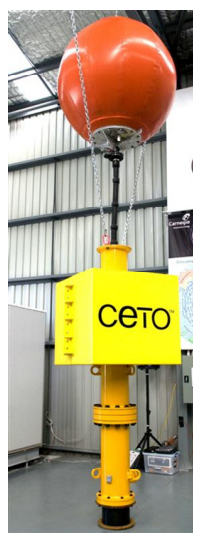

(b) Module. POWER
TO THE USER

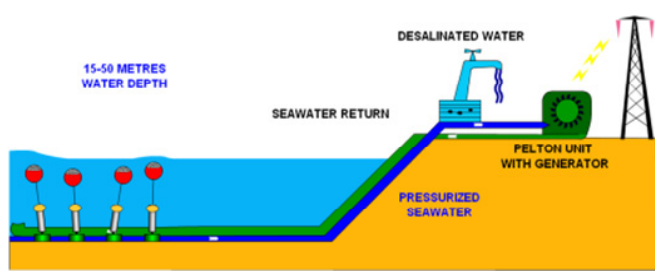

(c) Principle

Fig. 6. CETO project illustration [8].

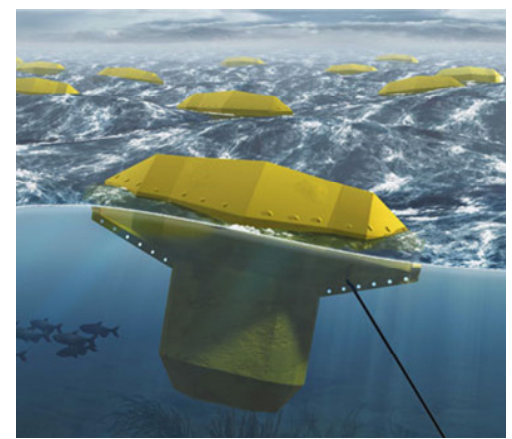

(a) Farm.

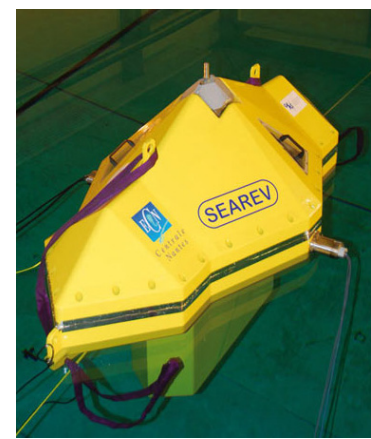

(b) Actual module.

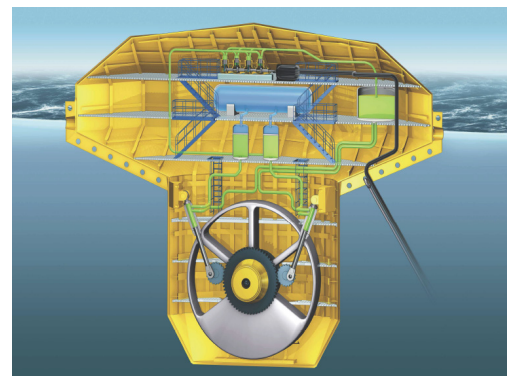

(c) Module details

Fig. 7. The SEAREV project illustration [9-10].

OYSTER project (UK) [11]: The OYSTER WEC has been designed to capture energy found in near shore waves (Fig. 8). It is a buoyant, hinged flap which is attached to the seabed at around 10-m depth, around half a kilometer from shore. This hinged flap, which is almost entirely underwater, sways backwards and forwards in the near shore waves. The movement of the flap drives two hydraulic pistons which push high pressure water onshore to drive a conventional hydroelectric turbine. 


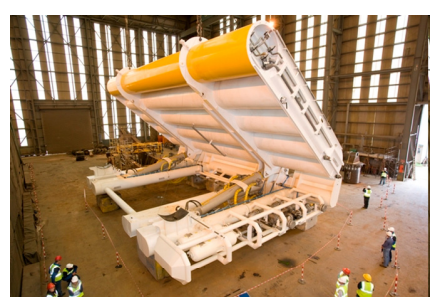

(a) Full-scale module. OYSTER' WAVE

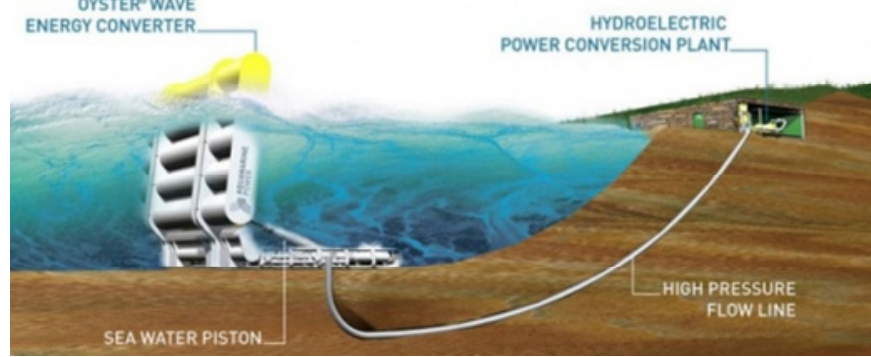

(c) Principle.

Fig. 8. The OYSTER project illustration [C Aquamarine Power].

The first full-scale OYSTER 1 wave power device was installed at the European Marine Energy Centre (EMEC) in Orkney (Scotland) in the summer of 2009 and was connected to the grid in November 2009. OYSTER 1 is currently undergoing sea trials.

\section{Oscillating Water Column}

An Oscillating Water Column (OWC) is a partially submerged, hollow structure (Figs. $4 \mathrm{~d}$ and 9). It is open to the sea below the water line, enclosing an air column on top of a water column. Waves cause the water column to rise and fall, which in turn compresses and decompresses the air column. This trapped air is allowed to flow to and from the atmosphere via a turbine, which usually has the ability to rotate regardless of the direction of the airflow. The rotation of the turbine is used to generate electricity [12].

The OWC WEC most used air turbines are the Wells and the Impulse ones. The Denniss-Auld type is also used [1].

1) OCEANLINX project (Australia) [13]. OCEANLINX is a floating device using the OWC principle (Fig. 10). When the wave rises within the $\mathrm{OWC}$, as the wave rises within the OWC, it replicates a piston action driving an air column ahead of it and drives the turbine. As the wave recedes, the air is sucked back into the OWC and also drives the turbine.

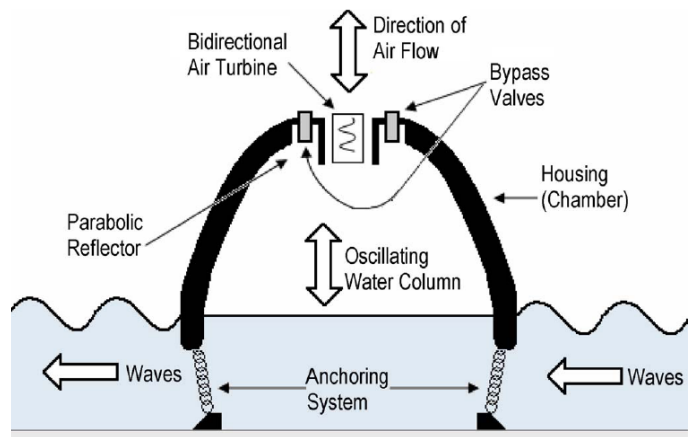

Fig. 9. Oscillating water column principle [5].

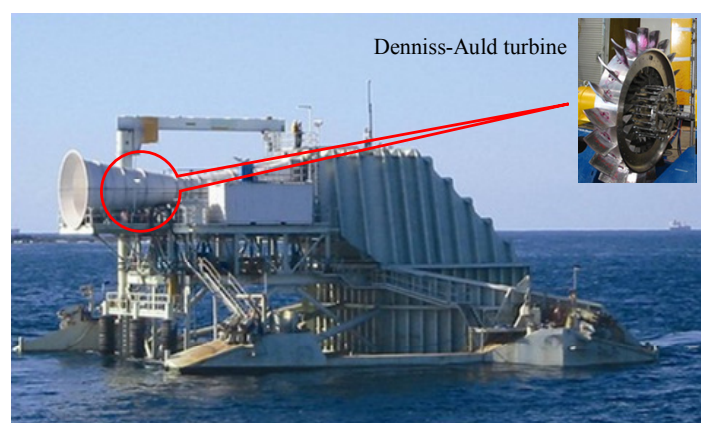

(a) Full-scale module.

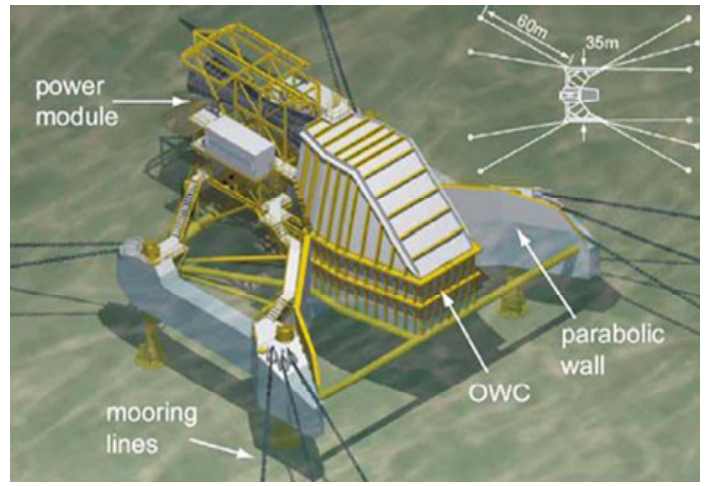

(b) Module details.

Fig. 10. The OCEANLINX project illustration [C oceanlinkx].

For efficiency maximization, the OWC cross sectional area is narrowed as it approaches the turbine. The Denniss-Auld turbine has been designed for that purpose. It has variable pitch blades that can be controlled to maintain a constant direction of the generator rotation and to optimize the energy extraction.

2) LIMPET project (UK) [14]. LIMPET (Land Installed Marine Powered Energy Transformer) is a shoreline WEC ideally placed to generate electricity in areas exposed to strong wave energy. It is placed on the island of Islay, off Scotland west coast (Fig. 11). The current LIMPET device (LIMPET 500) was installed in 2000 and produces power for the UK grid.
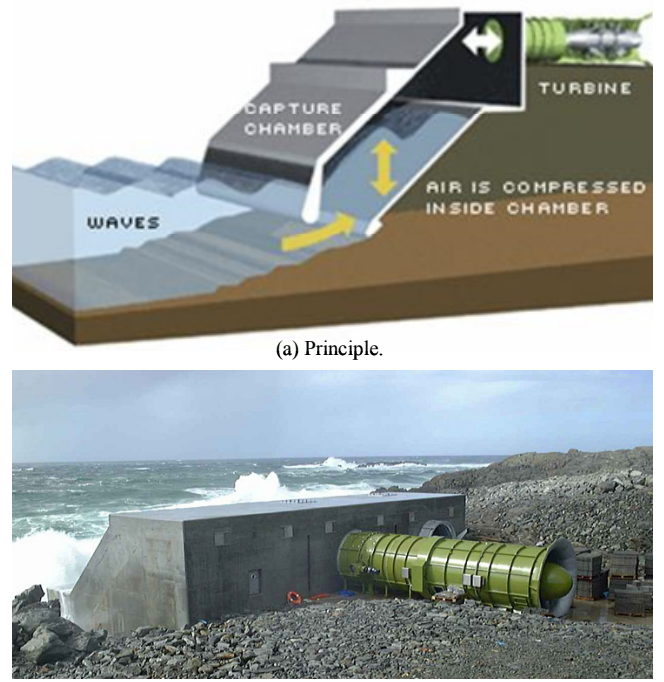

(b) Islay installation

Fig. 11. The LIMPET project illustration [C oceanlinkx]. 
1) PICO plant (Portugal) [15]. This plant consists of a hollow reinforced concrete structure (pneumatic chamber) above the water free surface that communicates with the sea and the incident waves by a submerged opening in its front wall, and with the atmosphere by a fiber duct with an air turbine. The OWC inside the chamber forces air alternately to and from the atmosphere via a Wells turbine with symmetric blades (Fig. 12).

Initial tests between 2005 and 2006 yielded a total production of around 1-MWh.

\section{E. Overtopping Device}

This type of WEC relies on physical capture of water from waves which is held in a reservoir above sea level, before being returned to the sea through conventional low-head turbines which generates power. An overtopping device may use collectors to concentrate the wave energy (Figs. 4e and 13) [5]. The WAVE DRAGON project is good illustration of this type of WEC.

WAVE DRAGON project (UK) [16]: WAVE DRAGON is an offshore floating overtopping WEC device. It consists of two parabolic reflecting arms, a double curved overtopping ramp, a storage basin and multiple low head turbines (Fig. 14).

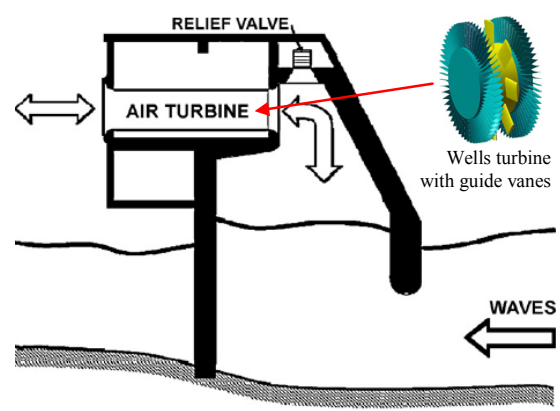

(a) Cross-sectional view of the plant

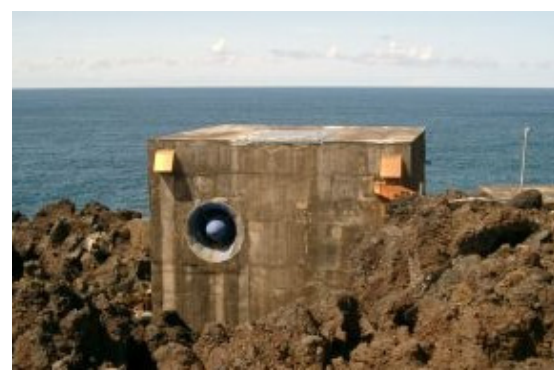

(b) Back view of the plant.

Fig. 12. PICO plant illustration [@ Wave Energy Center].

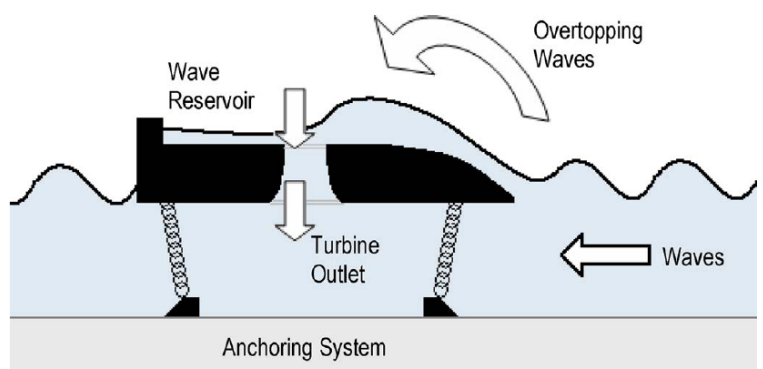

Fig. 13. Overtopping WEC principle [5].
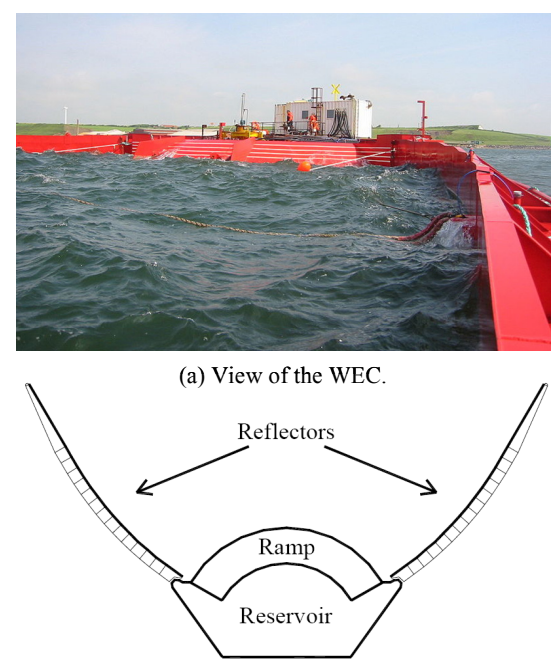

(b) Main components of the Wave Dragon.

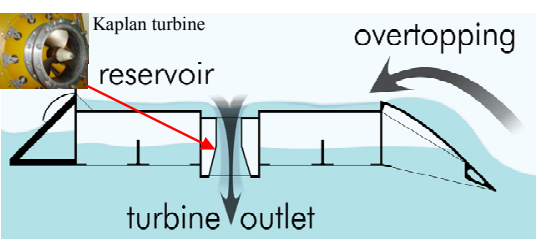

(c) Basic principle of the Wave Dragon

Fig. 14. The WAVE DRAGON project illustration [C Wave Dragon].

The reflecting arms focus waves onto the overtopping ramp and into the storage basin above sea level. From the basin the water flows through modified Kaplan-turbines and generates electricity. This WEC is slack moored and can orientate itself to face into the dominant wave direction.

Since 2003, a scale-model of the WAVE DRAGON device has been deployed in Denmark and connected to a public power grid.

\section{F. Submerged Pressure}

These WECs, also called Direct Drive, are typically located near shore and attached to the seabed. The motion of the waves causes the sea level to rise and fall above the device, inducing a pressure differential in the WEC. The alternating pressure can then pump fluid through a system to generate electricity. The ARCHIMEDES WAVE SWING (AWS) is the typical project in this case.

AWS project (AWS) [17]: The typical configuration is shown in Figs. 4f and 15.
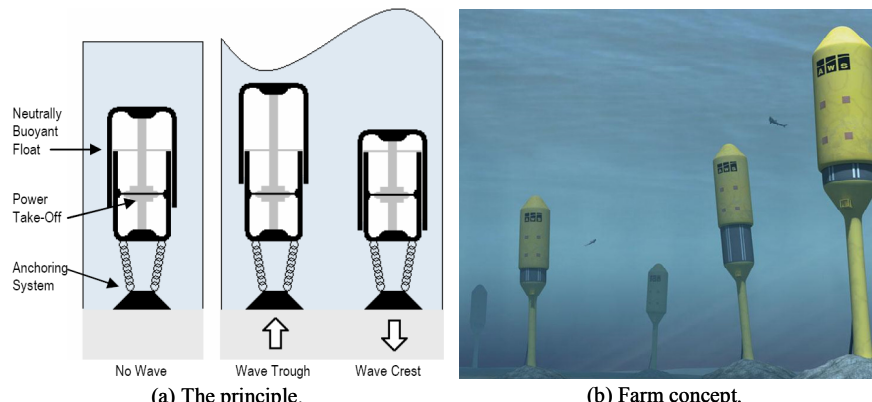

(b) Farm concept.

Fig. 15. The AWS WEC principle [5]. 
The AWS consists of a hollow cylinder and a lid, called floater. The cylinder is filled with air, and is fixed on the seabottom. The floater moves in the vertical direction. When the wave comes, the floater sinks because of increase of the weight of the water above, while the pressure of the air in the cylinder increases; when the wave trough is above the AWS, the weight of the water above decreases, and the floater moves up by the pressure of the air in the cylinder [18]. Energy is then extracted from the floater reciprocating motion.

The pilot plant depicted in Fig. 16 has been submerged in September 2004 offshore the Portugal coasts.

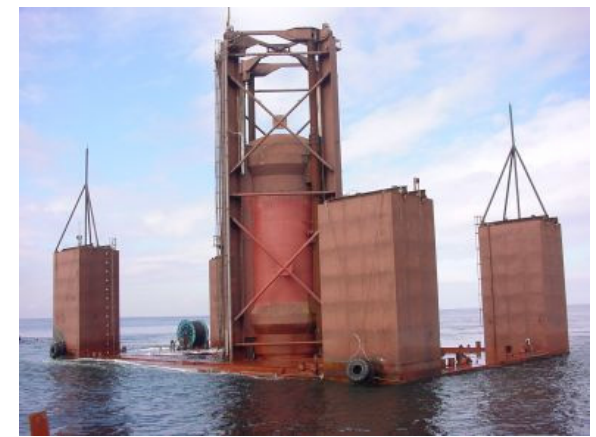

Fig. 16. AWS Photos before submerging.

\section{ELECTRICAL GENERATOR IN WAVE ENERGY GENERATION}

In all WECs, a mechanical interface is used to convert the slow rotational speed or reciprocating motion into high speed rotational motion for connection to a conventional rotary electrical generator.

Linear generators (direct drive) is an option, but is not yet currently used in the most developed WECs [12]. In this case, different types of linear generators were investigated for AWS wave energy converters [19-20]. These investigations have led to the conclusion that the transverse flux permanent magnet generator is a good candidate for wave energy applications in terms of higher power density and efficiency.

The use of induction generators implies a specific mechanical PTO that induces additional losses affecting the WEC overall efficiency. This drawback can be avoided by using a direct drive approach. However, there are still mechanical engineering challenges to be overcome in integrating direct drive in WEC where the major issues are size and weight.

Table 1 summarizes the PTO systems and the electrical generator options for the above presented WECs. However, generator type comparison is not quite trivial for WEC. Indeed, it needs to take into account the generator structural integration into the wave energy converter [12].

\section{CONCLUSION}

This paper has attempted to review fundamental concepts and the main wave energy projects around the world. The emphasis has been put on devices types and concepts. Moreover, it has been also reported issues regarding the associated electrical generator topologies.
TABLE 1. POWER TAKE-0FF SYSTEMS AND GENERATORS. (DFIG: Doubly-Fed Induction Generator, PMSG: Permanent Magnet Synchronous Generator, LPMG: Linear Permanent Magnet Generator)

\begin{tabular}{|c|c|c|c|}
\hline Device & PTO & Generator & Speed \\
\hline PELAMIS & Attenuator/Hydraulics & Induction & Fixed \\
\hline SEAREV & Point Absorber & $P M S G$ & Variable \\
\hline OYSTER & $\begin{array}{l}\text { Oscillating Wave } \\
\text { Surge Converter }\end{array}$ & Induction & Variable \\
\hline LIMPET & OWC \& Wells turbine & Induction & Variable \\
\hline OCEANLINX & $\begin{array}{c}\text { OWC \& Denniss-Auld } \\
\text { turbine }\end{array}$ & Induction & Variable \\
\hline PICO & $\begin{array}{l}\text { OWC \& Wells turbine } \\
\text { with guides vanes }\end{array}$ & $D F I G$ & Variable \\
\hline $\begin{array}{l}\text { WAVE } \\
\text { DRAGON }\end{array}$ & $\begin{array}{l}\text { Overtopping \& Kaplan } \\
\text { turbine }\end{array}$ & $P M S G$ & Variable \\
\hline AWS & Direct Drive & $L P M G$ & Variable \\
\hline
\end{tabular}

\section{REFERENCE}

[1] J. Crus Ed., Ocean Wave Energy: Current Status and Future Perspectives. Springer, Berlin, 2008.

[2] J.G. Vining et al., "Economic factors and incentives for ocean wave energy conversion," IEEE Trans. Industry Applications, vol. 45, n 2 pp. 547-554, March-April 2009.

[3] M.E.H. Benbouzid et al., "Marine tidal current electric power generation technology: State of the art and current status," in Proceedings of IEEE IEMDC'07, Antalya (Turkey), vol. 2, pp. 1407 1412, May 2007

[4] J. Falness, "A review of wave-energy extraction," Marine Structures, vol. $20, \mathrm{n}^{\circ} 4$, pp. 185-201, October 2007.

[5] A. Muetze et al., "Ocean wave energy conversion - A survey," in Proceedings of the IEEE IAS'06, Tampa (USA), vol. 3, pp. 1410-1417, October 2006.

[6] http://www.emec.org.uk/ (last accessed September 2010).

[7] http://www.pelamiswave.com/(last accessed September 2010).

[8] http://www.ceto.com.au/(last accessed September 2010).

[9] A. Babarit et al., "SEAREV: a fully-integrated wave energy converter," in Proceedings of the OWEMES'09, April 2006.

[10] A. Babarit et al., "Declutching control of a wave energy converter, Ocean Engineering, vol. 36, n $12-13$, pp. 1015-1024, September 2009.

[11] http://www.aquamarinepower.com/ (last accessed September 2010).

[12] M.A. Mueller et al., "Current and novel electrical generator technology for wave energy converters," in Proceedings of the IEEE IEMDC'07, Antalya (Turkey), vol. 2, pp.1401-1406, May 2007.

[13] http://www.oceanlinx.com/(last accessed September 2010).

[14] www.wavegen.co.uk/ (last accessed September 2010).

[15] http://www.pico-owc.net/ (last accessed September 2010).

[16] http://www.wavedragon.net/(last accessed September 2010).

[17] http://www.awsocean.com/(last accessed September 2010).

[18] F. Wu et al., "Modeling and control of AWS-based wave energy conversion system integrated into power grid," IEEE Trans. Power Systems, vol. 23, n³, pp. 1196-1204, August 2008.

[19] H. Polinder et al., "Conventional and TFPM linear generators for directdrive wave energy conversion," IEEE Trans. Energy Conversion, vol 20, no. 2, pp. 260-267, June 2005.

[20] M.A. Muller, "Electrical generators for direct drive wave energy converters," IEE Proc. Generation, Transmission \& Distribution, vol. $149, \mathrm{n}^{\circ} 4$, pp. 446-456, July 2002 